\title{
The Healing Power of Extraordinary Spiritual Experiences
}

\author{
David Hufford, Ph.D. \\ Pennsylvania State University and Samueli Institute
}

\begin{abstract}
Extraordinary spiritual experiences (ESEs), events that appear to be direct perception of spiritual facts, have a history in Western societies of being stigmatized and pathologized except within very limited religious contexts. That negative view has caused real harm to many "visionaries." But in the latter 20th century, social science research began to show that ESEs are actually common in the general population and that they are normal. Near-death experiences are a well-known example. The growing body of research literature suggests that many conventional theories about spirituality are empirically mistaken and that ESEs may have the potential to be powerfully health promoting. This emerging evidence creates both a great ethical obligation and a research opportunity.
\end{abstract}

KEY WORDS: spiritual experience, near-death experience, after-death communication, healing, sleep paralysis

Although I will include some quantitative data in this paper, my primary source is ethnographic accounts: rich and complex descriptions rendered in words rather than numbers-what Clifford Geertz (1973) called "thick description." A common criticism of research on such phenomena as near-death experiences (NDEs) is that they are supported largely by anecdote. An anecdote is a brief, informal account of an event that contains only enough information to convey a main point. As with any topic of great human interest, there are, indeed, many

David J. Hufford, Ph.D., is University Professor Emeritus at the Pennsylvania State University College of Medicine. He serves currently as Senior Fellow in Brain, Mind \& Healing at the Samueli Institute in Alexandria, VA. This paper was presented at the American Center for the Integration of Spiritually Transformative Experiences 2nd Annual Conference on Therapeutic Issue of Spiritually Transformative Experiences, Arlington, VA, October 4, 2013. Correspondence regarding this article should be sent to Dr. Hufford at email: djh5@psu.edu. 
anecdotes about NDEs and similar phenomena. These accounts are part of the normal human process by which information is shared, and they are genuinely informative-though very limited as scientific data. Anecdotes, case studies, and ethnographic accounts are all forms of qualitative data, but the latter two are much more than anecdotes by virtue of their extensive and detailed nature that lends them more readily to hypothesis creation and testing.

In 1984, I reviewed a manuscript for the University of Pittsburgh Press. Written by an elderly psychologist, Genevieve W. Foster, it was a memoir centered on a transformative spiritual experience she had in 1945. I recommended publication and collaborated with Gen on the final product, The World Was Flooded with Light: A Mystical Experience Remembered (Foster, 1985), interviewing her at length, and corresponding with her about details of her experience and its meaning to her. Gen's memoir was 83 pages long, but the experience itself occupied only two pages. Yet the ramifications of that experience touched every part of her life: It was "so far from anything that I had thought in the realm of the possible, that it has taken me the rest of my life to come to terms with it" (p. 36). At the time of her experience Gen was in her thirties, married, and in training to become a Jungian psychotherapist. Things were going well for her, and she was not under any particular stress or other factor that would have been expected to precipitate a life-changing mystical event.

The experience occurred one March afternoon. Alone in the house, she took an afternoon nap. When she awoke, she experienced

a visitation that all my upbringing and education had told me was simply an impossibility - unless of course one was psychotic.... I saw nothing unusual with my outward eye, but nevertheless I knew that there was someone else in the room with me. A few feet in front of me and a little to the left stood a numinous figure, and between us was an interchange, a flood, flowing both ways, of love. There were no words, no sound. There was light everywhere ... the world was flooded with light, ... The vision lasted five days. ... There was no one around to whom I could tell it. Roger (my husband), who is embarrassed at the mere mention of religious experience, would have thought me utterly mad, as I surely would have thought anyone mad who told me such a story. ... Yet the experience was so overwhelmingly good that I could not mistrust it. (Foster, 1985, pp. 42-43)

For five days the presence was with her constantly as she went about her normal routines and activities. The light continued so that "indeed everything around us, our house, the flowering world outside, 
the college where I worked, the commuter train I rode-and all these people and things I saw now sub specie eternitas, bathed in that supernal light" (Foster, 1985, p. 46).

Over the next 35 years, Gen told only three people of the experience. The first was a psychologist mentor who considered it a grave symptom, thus ending their relationship. Then a few years later, thinking that she should seek knowledgeable guidance, she made an appointment with a clergyman. As Gen began to describe the experience to him, he became alarmed, telling her that she needed to see a physician, that he suspected she was entering menopause prematurely. So she stopped speaking of her experience. But a few years later she was counseling a college student whom she thought was suicidal. She told that young woman about the experience because she thought that "she needed to know what I had learned, that the world is not what it seems."

But what was Gen's transformation? "The reader who asks 'Just how did it change your life?' must see, I think, that even though such a vision has faded, life can never return to its former pattern" (Foster, 1985, p. 46). She said that even after the vision ended,

I knew that I was 'companioned' and that the Companion was numinous.... I have had ever since an intuitive awareness of being 'companioned.' That numinous presence is still there, I know, and it is the deficiency of my vision that prevents me from seeing it. As it is there for everyone, I am convinced, as it was for Arjuna, whose charioteer had been the divine Krishna all along. . . . So yes, surely my relation to my family was affected-it could not have been otherwise, and so was my relation to my work in the world. ..." (p. 48)

This was not a transformation just in attitude or feeling. A world with a constant, loving, invisible companion was a different world, not the disenchanted world of psychology and modernity that Gen had been taught to expect. As the world was transformed, so was she. But she knew that her new vision of the world was heresy.

So for almost 40 years Gen kept her own counsel, silenced by modern prejudice ironically enforced by her own field of psychology. Then, facing surgery that she thought she might not survive, she decided to inform her family: Thus, her memoir. Gen and I dedicated the book to those who have had "a visionary experience without the benefit of a visionary tradition. . . . By deciding to break our culture's rules about who should admit to such experiences, she offers some much needed company to others who have been isolated by those rules" (Foster, 1985, xi-xii). 


\section{Defining Spirituality}

Transformative spiritual experiences are a human universal, found in every society and every historical epoch (Hood, 1995). From the birth of a baby to the death of a loved one, from deep encounters with nature to transcendent mystical experiences, people report that living through certain kinds of events can change a person profoundly. Neither all such events nor all transformations are spiritual-a term I discuss further below-but many are. In this paper I will be concerned with a particular kind of spiritual experience, extraordinary spiritual experiences (ESEs; Hufford, 2005), and the healing potential of the transformation that such experiences can produce. Gen Foster's experience is one kind of ESE, and the lasting spiritual transformation it produced in her illustrates the power of these events.

Gen's experience also illustrates what it means to say that an experience is spiritual. Unfortunately the academic literature on spirituality, especially the spirituality and health literature, is hampered by the use of vague and ambiguous definitions of the term. For example, in the authoritative Handbook of Religion and Health (Koenig, McCullough, \& Larson, 2001), spirituality is defined as

the personal quest for understanding answers to ultimate questions about life, about meaning and about relationship to the sacred or transcendent, which may (*or may not) lead to or arise from the development of religious rituals and the formation of community. (p. 18)

This kind of definition has shown remarkable stability. For example, in 2009 the National Consensus Project for Quality Palliative Care, in the second edition of their Clinical Practice Guidelines for Quality Palliative Care, asserted that

Spirituality is the aspect of humanity that refers to the way individuals seek and express meaning and purpose and the way they experience their connectedness to the moment, to self, to others, to nature, and to the significant or sacred.

These definitions make no reference to spirit, and even "transcendence" and "sacred" are used in a very ambiguous manner. Such problems are common when scientific fields appropriate natural language terms for technical use. To the extent that operationalized technical definitions meet the conceptual criteria of investigators, they often lose the meanings that they have in ordinary speech. The result for research is equivocation and loss of validity, especially when, in spirituality and health research, questionnaires based on the academic defi- 
nition conflate spiritual and psychological factors. For example, the 12 -item Functional Assessment of Chronic Illness Therapy-Spiritual Well-being Scale (FACIT-Sp; Peterman, Fitchett, Brady, Hernandez, $\&$ Cella, 2002) is a popular measure of the religious/spiritual (R/S) components of patients' quality of life. The original factor analyses of the FACIT-Sp indicated that it was composed of two factors: Meaning/ Peace and Faith. The scale has been used to show that spirituality increases patient wellbeing. But the Meaning/Peace subscale could just as easily be found on secular measures of life satisfaction, happiness, and wellbeing (Zinnbauer \& Pargament, 2005, p. 31), and the Peace subscale is essentially a measure of emotional wellbeing (Peterman et al., 2014). When researchers use such measures to assess the effect of spirituality on psychological health, as they often do, the results are useless and misleading, because they are tautological (Koenig, 2008, p. 349). Investigators seek the correct meaning of terms, but for naturally occurring language, the only correct meanings are those found in customary usage, and the correct meaning, as Emblen concisely pointed out, "depends on how the ambient community commonly uses the terms" (Emblen, 1992, p. 41). Community meanings are discovered through lexical research based on the observation of large numbers of naturally occurring utterances; they cannot be derived from academic theories.

The reshaping of ordinary language for technical use has political as well as scientific dimensions. Definitions of spirituality that focus on making meaning, which encompasses virtually any kind of personally significant meaning, rather than on spirit, reflect at least three powerful and related forces: the secularist attitude of science and medicine in general, the influence of existential Christian philosophyespecially the work of Paul Tillich, and the tacit theological commitments of many physicians and scientists. These factors combine to push the definition of spirituality away from its traditional meaning. That traditional meaning is simple, clear, concise, and well established by lexical research.

According to the authoritative New Shorter Oxford English Dictionary, the meaning of spirituality and its root, spirit has been stable for centuries. Spirituality has two sets of meanings, both originating in late Middle English. The first, now archaic, refers to the clergy and ecclesiastical property. The second, still the common meaning, is "the quality or condition of being spiritual; regard for spiritual as opp. to material things" (Brown, 1993, p. 2990). Spiritual means "1. Of, pertaining to or affecting the spirit or soul...." (p. 2990). And spirit means 
1. The animating principle in humans and animals. 2. The immaterial part of a corporeal being. 3. A supernatural, immaterial, rational or intelligent being, usu. regarded as imperceptible but capable of becoming visible . . . as an angel, demon, fairy, etc. (p. 2989)

When spirituality refers to something else, it is by metaphorical extension to other intangible and invisible things, such as ideas, as in "team spirit" or the "spirit of democracy," or "wines and spirits." The latter reference comes from 17th century chemistry and anatomy where "animal spirits" were believed to be a class of highly refined, invisible particles, analogous to those invisible vapors emitted by volatile liquids such as alcohol, that move through the nervous system-thus, "wines and spirits" (see, for example, Rousseau, 1990). This was an early effort to produce a reductive, materialist theory of mind.

The traditional, lexical meaning of spirituality is derived from a massive quantity of empirical research in lexicography, the branch of linguistics in which scholars study the meaning of words and create dictionaries. In lexicography the meaning of words is derived from actual instances of usage, employing meanings from a corpus that may include millions of utterances. The lexicographic definition simply is what spiritual has meant in general English language usage for centuries. A recent European study supported this linguistic finding with social science methodology. Using their new spirituality scale in two large studies, the researchers found

that [in study $1, N=1,931$ ] religiosity and beliefs pertinent to supernatural spirits predicted most of the variation in spirituality. . . . [Study $2, N=848$ ] showed that the stronger belief in supernatural spirits, the more the person experienced subjective spirituality; that belief in supernatural spirits had higher predictive value of spirituality than religiosity, paranormal beliefs, or values; and that most of the relationship between religiosity and spirituality could be explained through belief in supernatural spirits" (Lindeman, Blomqvist, \& Takada, 2012, p. 167).

\section{Normalizing Extraordinary Spiritual Experience}

The vague academic definition centered on meaning generally fails even to note the widespread acceptance of the reality of spirits by modern people; thus, it indirectly serves to exoticize the belief in spirits in modern society. In contrast, the accurate lexical definition highlights the fact that belief in spirits remains common among modern 
people. This fact, if fully accepted, would help to normalize spiritual experience. It was the immaterial and invisible numinous companion that stigmatized Gen's experience, a companion that fits the ordinary English definition of spirit! And it is this, the personally convincing evidence, as Gen put it, that "the world is not what it seems," that is powerfully healing in these experiences: Loss is not loss; death is not death. In psychological terms, ESEs cognitively reframe one's life.

ESEs stand in contrast to "ordinary spiritual experiences." The latter experiences become spiritual for the subject through interpretation that usually arises from prior learning such as religious teachings. For example, a beautiful sunset may be a spiritual experience for a religious person but a purely esthetic experience for an atheist. By contrast, ESEs are events that appear to the subject to involve the direct perception of spiritual facts, such that if they are not hallucinations, then they must be veridical perceptions of spiritual reality (Hufford, 2005). Gen Foster's (1985) experience is a perfect example. The reference of such experiences to spirituality in the traditional sense is not dependent on learned interpretations; if one seems to encounter a nonmaterial being, a spirit, then the experience is either genuinely spiritual or it is a hallucination.

Throughout history people have reported ESEs, including mystical experiences, visits from deceased loved ones, journeys to the afterlife and, on the dark side, spiritual attack. People reporting these experiences have included those from the West-until the modern era. But as Max Weber (1917/2004) said of modernity,

the growing process of intellectualization and rationalization ... means that in principle, then, we are not ruled by mysterious, unpredictable forces, but that, on the contrary, we can in principle control everything by means of calculation. That in turn means the disenchantment of the world. Unlike the savage for whom such forces existed, we need no longer have recourse to magic in order to control the spirits or pray to them. Instead, technology and calculation achieve our ends. This is the primary meaning of the process of intellectualization. (pp. 12-13)

Weber had mixed feelings about this disenchantment but considered it an inevitable part of intellectual progress. A major element of the disenchantment process is the ironic alliance of two forces-Western religion, beginning with the Protestant Reformation, and the skeptical materialism of the Enlightenment-against traditional spirit belief (Hufford, 2008). Beginning in the 16th century, Reformation theology radically narrowed the range of spirits available to humans. As John Cerullo (1982) put it, in contrast to the Medieval view of frequent 
supernatural-natural interactions, the God of the Reformation "would not grant such 'popish' boons to a mankind as utterly, frightfully fallen as Luther and Calvin believed. In the final analysis, only one undeniably supernatural event was allotted Protestants - the devolution of God's sovereign grace" (p. 3). In the 18th century, several proponents of the Enlightenment, especially David Hume, formulated the divide between natural philosophy (later science) and religion as between rationality and faith - faith defined as belief without evidence. During the Enlightenment the rapid development of successful material scientific explanations of the natural world together with philosophical skepticism put major pressure on the traditional authority of religion. Theologians struggled to find a comfortable home for religion in this newly dis-spirited place.

Yielding reason and evidence to science and abandoning supernatural intrusions into the mundane world removed major vulnerabilities in traditional religion, but at the same time it reduced the number of opportune openings for the "God of the gaps." Modern theology became increasingly existential-notably beginning with Friedrich Schleiermacher in the late 18th century - basing belief on feeling, given and supported by grace and faith, in this way removing religion's remaining exposure to critical argument (Proudfoot, 1985). With modern religion's Existential turn the idea of empirical evidence supporting religious belief came to be seen as immature.

In the 20th century, existentialism came to include Rudolf Bultmann's (1953) "demythologizing," the attempt to remove all that was supernatural from modern Christianity:

the mythical view of the world is obsolete. ... Man's knowledge and mastery of the world have advanced to such an extent through science and technology that it is no longer possible for anyone to seriously hold (such supernatural beliefs). . . Now that the forces and the laws of nature have been discovered, we can no longer believe in "spirits," whether good or evil. ... It is impossible to use electric light and the wireless and to avail ourselves of modern medical and surgical discoveries, and at the same time to believe in ... spirits. (pp. 3-5)

Such modern religious views are not limited to Christianity. They can be found, for example, in Rabbi Mordecai Kaplan's (1934/1994) ideas in Reconstructionist Judaism.

As ESEs were expelled from sophisticated modern religion, they moved to the margins of society where the experiential religion of Pentecostals and, later, Charismatics, was viewed as crude and possibly heretical. Yet even within the ecstatic spirituality of Christian reviv- 
alism, the variety of spiritual possibilities was kept very narrow; encounters with the Holy Spirit were highly valued, but most other spirit encounters were viewed with great skepticism as possibly demonic. An excellent example is provided Jan Gumprecht's (1997) book Abusing Memory: The Healing Theology of Agnes Sanford. Agnes Mary White Sanford (1897-1982) was one of the principal founders of the Inner Healing Movement, an approach that uses Christian language and claims to have recaptured the original healing approach of Jesus. She began her ministry through a transformative spiritual healing experience. But many Christians committed to healing insist that Sanford's approach is a form of spiritualism. Gumprecht's criticism of Sanford is summed up in the following passage from her book:

Jude 3 and 4 commands Christians to . . . be wary of those who have "crept in unawares" into our churches and "deny the only Lord God, and our Lord Jesus Christ." John tells us, "Beloved, do not believe every spirit, but test the spirits to see whether they be of God; because many false prophets have gone into the world." (1 John 4:1). (Gumprecht, 1997, p. 7)

Sanford is one of many visionaries whose spiritual practice is literally demonized by Christian spiritual healers. The breadth of this criticism is suggested by the following declaration: "Agnes Sanford was much influenced by Jung's ideas (which came from evil spirits) and 'Christianized' them, introducing visualization and inner healing" (Taylor, n.d.). So even as mainstream modern religion turned away from transcendental experience, experiential Christianity ironically provided additional barriers to the acceptance of all but a few transformative spiritual experiences.

The tense rapprochement between theology and scientific skepticism necessarily included an embrace of disenchantment and a rejection of spirit encounters as primitive. Although much modern religion retains limited belief in spirits, God, and the human soul, religious proponents conceive of these phenomena within a radically transcendent framework that does not allow for direct spirit encounters by living people. The effect is roughly the same. Inevitably, belief in spirits, let alone encounters with spirits, is exiled to the margins of civilization. If modern education and rationality prevent spirit belief, then such belief should be found in ancient and "non-Western" settings where such education and rationality are thought to be absent. Within modern society one would expect only the poorly educated to hold such belief. Finally, if modern well-educated persons believe in spiritsor say they have seen or heard them!-they must have lost their 
reason: They are insane. Thus, modern theology and modern skepticism enforce disenchantment with powerful sanctions against spirit belief: heresy and psychosis. As Freud (1927/1961) wrote, religious beliefs "are not the precipitates of experience or end results of thinking; they are illusions, fulfillments of the oldest, strongest and most urgent wishes of mankind" (Ch. 6, p. 38).

The great surprise of the late 20th century was the growing realization that contemporary consciousness is in fact not disenchanted, that belief in spirits persists, even among the well educated. This persistence is because encounters with spirits-ESEs-continue to occur without respect to education, cultural background, or prior belief (for example, Haraldsson, 1988; Holden, Greyson, \& James, 2009; Hufford, 1982, 2005, 2010; McClenon, 1994; Shushan, 2009; Streit-Horn, 2011), indicating the robust, cross-culturally stable patterns of ESEs. For example, in the mid-1970s, data began to appear showing that NDEs and after-death communications (ADCs; perceived visits to the bereaved and non-bereaved by the deceased) are common in the general population (Moody, 1975; Rees, 1971).

The term NDE was coined by Raymond Moody in 1975 in his book Life After Life. The readers of this journal are likely familiar with the basic history of NDE research, triggered by Moody's informal collection of accounts and soon followed by systematic, scientific research. There was intense medical skepticism at first about the high rate of prevalence suggested by Moody and about the independence of the pattern from cultural contexts (e.g. Vaisrub, 1977). But subsequent research has confirmed many of Moody's initial statements (Holden et al., 2009). Prior to these developments NDEs were consistently mistaken for symptoms of delirium. In fact, however, they are so different from delirium in content and clinical significance that it is hard to imagine mistaking them for a transient psychotic state (Hufford, 2010). That error highlights the extent to which modern assumptions about ESEs distorted and delayed accurate knowledge of them! Now NDEs are not only considered normal (Sadock \& Sadock, 2000, p. 810), but in longitudinal studies they have been linked to improved psychological and social health (e.g., van Lommel, van Wees, Meyers, \& Elfferich, 2001). Estimates of the prevalence of NDEs (i.e., the number of individuals in the population, or a particular sub-group, who have ever had one) range from $12 \%$ to $48 \%$ of resuscitants, varying by mode of near death, and as high as 15\% (Gallup, 1982, p. 198) or higher (Greeley, 1975) in the general population. And yet there remains intransigent skepticism in some quarters, and many people who report 
NDEs are still stigmatized (Foster, James, \& Holden, 2009; Noyes, Fenwick, Holden, \& Christian, 2009).

Although published research on ADCs as a feature of bereavement dates back to 1894 (Streit-Horn, 2011), these phenomena first came to modern medical attention through the work of physician W. D. Rees's (1971) "The Hallucinations of Widowhood" in The British Medical Journal. In a study of bereaved patients in the county of Wales where he practiced, Rees interviewed all competent widows and widowers regarding their adjustment to the loss of their spouse. Unexpectedly, he found that almost half had experienced what they considered a "significant and real" visit from the deceased (Rees, 2001, p. 273). As Rees commented in his 2001 textbook, Death and Bereavement, prior to the publication of his 1971 study these experiences were considered rare and pathological (Hufford, 2010). None of the doctors and only one of the clergy in the county had ever heard of these experiences. These reports were not significantly associated with religious faith, mode of death, social isolation, or depression. Weight loss was less likely among those reporting these experiences, and experiencers had significantly less sleep disturbance (2001, p. 270). In summary, the characteristics of these experiences were opposite to what had been assumed, published, and taught to medical students about "hallucinations" of the deceased during bereavement. In the 1975 edition of the Comprehensive Textbook of Psychiatry, such experiences were listed as primary symptoms of pathological grief (Freedman, Kaplan, \& Sadock, 1975, p. 1755), but responding to new research findings in the 2000 edition, these experiences were described as normal and common (Sadock \& Sadock, 2000, p. 810).

The incidence of ADCs during bereavement varies somewhat, depending on the relationship between the bereaved and the deceased. In his 1971 study, Rees found that $47.6 \%$ of widows and widowers reported having an ADC. The majority of subjects said that they found the ADCs helpful and reported less trouble sleeping than those bereaved subjects who did not report having had an ADC experience. In Greeley's 1973 national survey, he found a prevalence of $27 \%$ of respondents who reported having had at least one ADC. In 1999, palliative care physician Michael Barbato and associates conducted a study of next of kin of the deceased from an Australian palliative care unit and found that in the first six months after the death, $26 \%$ of subjects reported "visits" from the deceased. Despite the repeatedly confirmed commonality and benefit of ADCs, clinicians continue frequently to misunderstand these experiences. 


\section{Realizing the Healing Power of Extraordinary Spiritual Experiences}

NDEs and ADCs are the best-known examples of the profoundly transformative power of ESEs, but they are not the only ones. Persons approaching death often experience a visit from one or more deceased loved ones or other spiritual entities, having apparently come to accompany the dying in their transition from this life to the next (Osis \& Haraldsson, 1986; see also Fenwick \& Fenwick, 2011). These are typically consoling to the subject. One elderly woman told me that she was having spiritual visitors, saying "I know they're spiritual because they aren't coming in through the door." I asked if they were bothering her. She said, "No. It's my [deceased] mother and [deceased] sister. I think they've come for me." She died two days later, peacefully and appearing to be filled with a happy expectation. Unfortunately, family members are often distressed when their loved ones report such visits, even asking that they be medicated for delirium. These experiences present more missed opportunities. The dying would benefit from acceptance of their visions from those around them, and their family members could find consolation instead of anxiety if such events were not so thoroughly pathologized.

NDEs and ADCs illustrate the healing power of many ESEs, a power that comes in large part from information they reveal, information that changes the meaning of events (Noble, 1987). As Gen Foster said, "the world is not what it seems." In NDEs this healing power includes such things as being free from pain and physical limitations and being greeted by loving others, usually a "being of light" or predeceased family members and friends. In ADCs the deceased typically tells the survivor that they are fine, at peace, and that the bereaved should not grieve. In both cases the experience assures the subject that death is not what they thought or feared that it was. Fear of death is, according to many authors, the primary existential problem of humans. In bereavement, death is obviously the dominant cause of grief. But almost all subjects reporting NDEs and ADCs say that they no longer fear death, apparently because their experience assures them that death is not extinction, that they and their loved ones do not go out of existence but rather live on in a new way.

But, although caregiving professionals have become more familiar with ESEs and are better at responding appropriately, the general public has been slower. Family members are especially likely to interpret ESEs as pathological (Fenwick \& Fenwick, 2011; Pearson, 2014; 
van Lommel et al., 2001). Therefore, the reassurance of the experience itself is often hampered, even blunted, by the typical modern response subjects receive all too often when they speak of it, as illustrated by the following case.

One morning in 1995, one of our hospital chaplains called my office at Pennsylvania State University's medical center, asking me to speak with a man who had just been visited by his deceased wife. In a few minutes, the three of us sat in my department's conference room, and the man, in his 70s, told us the following story.

His wife had recently died in our hospital. On the previous day, shortly after his wife's funeral, he was in his living room, when his wife walked in. He was stunned. He told me, "I was amazed. I didn't know such things could happen. I never heard about it in church!" As for most modern people, this experience came out of a cultural void. She told him that she was all right and that he should not be so upset. They chatted briefly, and then she said good-bye, telling him that she had to go. He was distressed. He recalled asking, "Who says you have to go?" "Where will you spend the night?" But she was gone. He said that he was shocked, though he was glad to see her. He had questions. Why couldn't she stay? Who makes these rules? Why hadn't it occurred to him to reach out and touch her? Where would she spend the night? He tried to speak about the experience with his daughter, a very religious woman, but it upset her. She said, "Never speak to me about that again!" But he couldn't let go of it. The next day he had been grocery shopping when he decided he had to find someone who could talk with about this experience. He had left the groceries, gotten in his car, and driven an hour and a half to our medical center where he asked for a chaplain.

I told him that I have spoken with many other people who have had such experiences, that they are well known in the grief literature, and that they are normal. I said that those who have told me about their visits have considered them a beautiful and consoling gift, a sign of love. He was pleased and relieved, comforted by this common human experience. His anxiety was dissipated by the knowledge I offered, knowledge that our culture should have already provided but, instead, suppressed.

It is ironic, even tragic, that these experiences cause anxiety for subjects in modern society. That sad problem has been documented scientifically, for example, in the aforementioned Australian palliative care unit study by Barbato et al. (1999). They undertook the study because of the growing literature documenting these experiences as healthy responses to loss. Finding that over one-fourth of their partici- 
pants acknowledged such experiences, they recommended that those close to palliative care patients be counseled and reassured about such experiences, because occurring as they do in a cultural setting that has long pathologized visionary events, they create anxiety even as they offer consolation. These authors chose to call the visits "parapsychological phenomena near the time of death," noting that "the term hallucination still carries with it the stigma of mental disease" (p. 31). I might add that hallucination also carries the explicit meaning of a false perception.

But for these experiences to achieve their maximum potential to comfort and reassure, these shockingly "unmodern" events call for reflection, social support, and input from others in order for subjects to integrate them into their understanding of the world and their place in it. Also the information that comes from such experiences must be perceived as valid; ADCs, for example, would not assuage grief if they were taken to be symbolic expressions of the bereaved person's deepest wishes, as Freud (1919/1961) suggested. And in order for these experiences to be considered adaptive rather than neurotic or psychotic, that perception of validity must be rational. Rationality does not require that ESEs be proven real and objective phenomena, as they seem to the subject. Rather, it means that the subject must have good reasons to believe their experiences are real; good reasons and critical thinking do not guarantee correct conclusions, but they do distinguish rational thought from neurotic wish fulfillment and thought disorder. The exact source, nature, and meaning of ESEs is not well understood in scientific terms; therefore, their reality is controversial. Nonetheless, their subjective characteristics, the frequent confirmation of the veridicality of perceptions not explicable in ordinary physical terms (Holden, 2009), and the discovery that others have had very similar experiences-all these factors do provide good reason for subjects with sound reality testing and critical thinking skills to believe that their ESEs are valid and real. Because none of the current counterexplanations have well-established evidence (Holden et al., 2009), experiencers' reasons provide rational warrant for belief.

Some ESEs are frightening rather than joyful. I have studied sleep paralysis, a transient inability to move just before or after sleep, very often accompanied by a threatening spiritual presence (Hufford, 1982, $2005,2010)$. These experiences share the persistent conviction of reality and the remarkable cross-cultural pattern of content that characterize other ESEs. They are also quite common-about 18\% of subjects in my data (Hufford, 2005) - and they are not symptoms of psychiatric 
illness. Unfortunately, though, they are often misdiagnosed in a variety of ways (Hufford, 2010). Also, a minority of NDEs is terrifyingly unpleasant (Bush, 2009). Nevertheless, unpleasant, frightening ESEs still can be transformative, appearing to reveal another, non-material aspect of existence. But these ESEs also raise the perennial spiritual question of "Why me?" Those who have frightening ESEs have a great need for reflection and support. Like other ESE subjects, these experiencers are not helped when others tell them that they "just imagined it."

Unfortunately, many modern responses, from the clergyman who told Gen Foster that her mystical experience was a symptom of premature menopause, to the widower whose daughter forbade him to speak of his wife's consoling after-death visit, to the typically skeptical commentaries published in scientific publications-for example, Michael Shermer's (2003) comments in Scientific American regarding Pim van Lommel's NDE research-work against what the subjects of ESEs most need (van Lommel, n.d.). Gen Foster's 40-year sojourn with her mystical experience held secretly and in silence demonstrates how no amount of negative social attitude obliterates these life changing events-but the cost in terms of missed opportunities is enormous. Among those opportunities is the potential effect of ESEs on those who have not had them.

One who has never had an ESE but has only heard about them is likely to be more influenced by negative social attitudes and the statements of authorities than the visionary is. The result is that modern society has been largely deprived of the salutogenic effects that widespread knowledge of ESEs can offer. This is one of the basic functions of culture, to disseminate experiential knowledge beyond those with direct experience. I had the good fortune to observe a sort of unintentional natural experiment showing how this process can happen.

In the 1980s and early 1990s I took part as faculty at The Fife Conference, an annual public seminar, at Utah State University in Logan, Utah. My role was to lecture and present cases related to spirituality and health. At one such seminar I told about my mother's NDE, which she had in a hospital in Sayre, Pennsylvania in 1975. As in many NDEs, Mom was given the choice either to go with the deceased loved ones who came to meet her or to remain in earthly existence. Also common to NDErs was her decision to remain because she felt there was some important task she still needed to take care of-although she did not know what that might be. Occasionally she would call me and say she had thought of a possibility, something that needed to be done, usually some mending of relationships within the family. But 
then, in 1984, at the age of 76, my father was diagnosed with Alzheimer's Disease. That's it my mother told me. That is what she had stayed here for. And for the next five years she worked tirelessly to take care of my father at their home in upstate New York. When the effort became too great, I moved them to my home in Pennsylvania, and Dad died there in late February of 1990. As his death approached, my mother and I discussed how her NDE changed the way she thought about Dad's impending death. And when he died one morning before dawn, Mom, who slept in the same room with him, heard his breathing cease. At that point she assumed that he was up near the ceiling, as she had been in her NDE, and that like her he could see and hear what was happening. At that time she spoke with him, confident that he understood her, something she had not been able to do for years. For both her and my entire family, Mom's NDE made Dad's death different from what it otherwise would have been.

During the Fife Conference where I told of Mom's NDE and Dad's death, the father of my host lay in a local nursing home in the final stages of Alzheimer's. The day I told my story, he retold it at the dinner table to his family. The next day his adult daughter and her five-year-old son went to the nursing home for a visit. But when they arrived at her grandfather's room, she found him dead. They were the first to discover his demise. This can be a very distressing event, especially when young children are involved. But in this case, she recalled the story of my mother and reminded her son of it. She said that grandfather was probably right there, up by the ceiling, seeing and hearing everything. So they had that kind of comforting, though oneway, conversation my mother had had. When I spoke with her about this experience, she said that knowing of Mom's NDE and her reaction to my Dad's death had been very helpful to her and her young son. What had been an occasion of remarkable serendipity and good luck in this case is what normally happens in societies where NDEs are well known and integrated. This is, I believe, the origin of traditions of "wakes" for the dead, a purpose barely imaginable in the modern practice of "visiting hours" at the funeral home! The demise of such a cultural practice is part of what the modern rejection and cultural erasure of NDE knowledge has cost our society.

As awareness of ESEs has developed over the past few decades, cultural forms have emerged analogous to those present in societies with a tradition of spiritual knowledge. These forms are many, including organizations such as the International Association for Near Death Studies, websites with listservs such as Aware Sleep Paralysis, auto- 
biographical publications like Gen Foster's, and discussion groups. The organization American Center for the Integration of Spiritually Transformative Experiences (ACISTE) is one such form. ACISTE takes as its mission the integration of such experiences and seeks to accomplish this purpose with high ethical standards, compassion, respect, and appreciation of diversity. These four values are central to understanding ESEs and to developing appropriate responsesresponses that encourage human growth and flourishing rather than stigma and suppression.

As sketched above, the conventional modern attitude toward ESEs is rooted in a pathology model based on cultural prejudice rather than empirical science. The resulting modern dismissal of ESEs as cultural products devoid of rational content is scientifically unfounded and unethical, contrary to the four major requirements of modern medical ethics: autonomy, beneficence, non-maleficence, and justice (Beauchamp \& Childress, 2009, 38-39). Autonomy refers to freedom from coercion. The social consequences of the modern attitude have been coercive, enforcing silence among experiencers and preventing systematic scientific research among scientists and scholars who must fear the consequences for their careers. Beneficence means doing for others what is in their best interest. Ample evidence suggests that the best interests of experiencers are served by respectful and compassionate listening, and this response is not supported by modern attitudes. Non-maleficence means "do no harm." Clearly misdiagnosis and sanctions against social support have harmed those who have had life changing ESEs; these responses also curtailed the salutary potential of ESEs for society as a whole. Justice refers to equitable treatment. The modern attitude toward ESEs constitutes inequitable treatment of individuals and ideas on the basis of tacit religious commitments by those with cultural authority.

Although the medical model has been the basis of negative, reductive explanations of ESEs, it is also medical practitioners and researchers who have led current efforts to recognize these powerful experiences as both contrary to the modern materialist paradigm and potentially health-promoting both for individuals and for society. Parapsychologists have studied this topic productively for more than a century but were never in a position to bring it into mainstream credibility. Medicine, focused more on practical matters of diagnosis and treatment than attacking or defending theory, and armed with very substantial resources and prestige, has turned the tide. The work of physicians such as Ian Stevenson, W. Dewi Rees, Raymond Moody, 
Bruce Greyson, Larry Dossey, and Pim van Lommel has established ESEs as normal, widespread, and potentially salutogenic. Although the interpretation of these experiences is still controversial in medicine, psychology, and other scientific fields, the experiences themselves have now been solidly established as robust and challenging human phenomena. The growing appreciation of ESEs among caregivers has greatly eased the burden felt over the years by experiencers like Gen Foster and countless others silenced by modern stigma. Because ESEs are an intimate aspect of life, suffering, loss, and death, caregivers-from nurses and doctors to clergy to psychologists and social workers - have a great obligation and opportunity to lead the way in undoing the damage done by the mistaken belief that modernity is disenchanted!

\section{References}

Barbato, M. C., Blunden, K., Reid, H., Irwin, H., \& Rodriquez, P. (1999). Parapsychological phenomena near the time of death. Journal of Palliative Care. 15(2), 30-7.

Beauchamp, T. L., \& Childress, J. F. (2009). Principles of biomedical ethics (6th ed.). New York, NY: Oxford University Press.

Brown, L. (Ed.). 1993. The new shorter Oxford English dictionary on historical principals: Vol. 2. Oxford, England: Oxford University Press.

Bultmann, R. (1953). The New Testament and mythology. In H. W. Bartsch (Ed.), Kerygma and myth (pp. 1-44). London, England: SPCK.

Bush, N. (2009). Distressing Western near-death experiences: Finding a way through the abyss. In J. M. Holden, B. Greyson, \& D. James (Eds.), The handbook of near-death experiences: Thirty years of investigation (pp. 63-86). Santa Barbara, CA: Praeger/ABC-CLIO.

Cerullo, J. J. (1982). The secularization of the soul: Psychical research in modern Britain. Philadelphia, PA: Institute for the Study of Human Issues.

Emblen, J. D. (1992). Religion and spirituality defined according to current use in the nursing literature. Journal of Professional Nursing, 8(1), 41-47.

Fenwick, P., \& Fenwick, E. (2011). The truth in the light. Guildford, UK: White Crow Books.

Foster, G. (1985). The world was flooded with light: A mystical experience remembered. Pittsburgh, PA: University of Pittsburgh Press.

Foster, R. D., James, D., \& Holden, J. M. Practical applications of research on near-death experiences. In J. M. Holden, B. Greyson, \& D. James (Eds.), The handbook of near-death experiences: Thirty years of investigation (pp. 235-58). Santa Barbara, CA: Praeger/ABC-CLIO.

Freedman, A. M., Kaplan, H. I., \& Sadock B. J. (Eds.). (1975). The comprehensive textbook of psychiatry (2nd ed.). Baltimore. MD: Williams and Wilkins.

Freud, S. (1961). The future of an illusion. In J. Strachey (Ed.), The standard edition of the complete psychological works of Sigmund Freud (Vol. 21, pp. 1-56). London, England: Hogarth Press. (Original work published 1927) 
Freud, S. (1961). The uncanny. In J. Strachey (Ed.), The standard edition of the complete psychological works of Sigmund Freud (Vol. 17, pp. 217-256). London, England: Hogarth Press. (Original work published 1919)

Gallup, G. (1982). Adventures in immortality: A look beyond the threshold of death. New York, NY: McGraw-Hill.

Geertz, C. (1973). The interpretation of cultures. New York, NY: Basic Books.

Greeley, A. M. (1975). Sociology of the paranormal: A reconnaissance. Sage Research Papers in the Social Sciences, Studies in Religion and Ethnicity (Vol. 3, series 90-023). Beverly Hills, CA: Sage.

Gumprecht, J. (1997). Abusing memory: The healing theology of Agnes Sanford. Moscow, Idaho: Canon Press.

Haraldsson, E. (1988). Survey of claimed encounters with the dead. Omega, 19(2), 103-113.

Holden, J. M. (2009). Veridical perceptions in near-death experiences. In J. M. Holden, B. Greyson, \& D. James (Eds.), The handbook of near-death experiences: Thirty years of investigation (pp. 185-212). Santa Barbara, CA: Praeger/ ABC-CLIO.

Holden, J. M., Greyson, B., \& James, D. (Eds.). (2009). The handbook of neardeath experiences: Thirty years of investigation. Santa Barbara, CA: Praeger/ ABC-CLIO.

Hood, R., Jr. (Ed.). (1995). Handbook of religious experience. Birmingham, AL: Religious Education Press.

Hufford, D. J. (1982). The terror that comes in the night: An experience-centered study of supernatural assault traditions. Philadelphia, PA: University of Pennsylvania Press.

Hufford, D. (2005). Sleep paralysis as spiritual experience. Transcultural Psychiatry, 42(1), 11-45.

Hufford, D. J. (2008). The priority of local observation and local interpretation in evaluating the 'spirit hypothesis.' In H. Wautischer (Ed.), Ontology of consciousness: Percipient action (pp. 273-312). Cambridge, MA: Massachusetts Institute of Technology Press.

Hufford, D. J. (2010). Visionary spiritual experiences in an enchanted world. Anthropology and Humanism, 3(2), 142-158.

Kaplan, M. (1994). Judaism as a civilization: Toward a reconstruction of American-Jewish life. Philadelphia, PA: Jewish Publication Society. (Original work published 1934)

Koenig, H. G. (2008). Concerns about measuring spirituality in research. Journal of Nervous and Mental Disease, 196(5), 349-355.

Koenig, H. G., McCullough, M. E., \& Larson, D. B. (2001). The handbook of religion and health. New York, NY: Oxford University Press.

Lindeman, M., Blomqvist, S., \& Takada, M. (2012). Distinguishing spirituality from other constructs: Not a matter of well-being but of belief in supernatural spirits. Journal of Nervous and Mental Disease, 200(2), 167-73.

McClenon, J. (1994). Wondrous events: Foundations of religious belief. Philadelphia, PA: University of Pennsylvania Press.

Moody, R. (1975). Life after life. Atlanta, GA: Mockingbird Books.

National Consensus Project for Quality Palliative Care. (2009). Clinical practice guidelines for quality palliative care (2nd ed.). Retrieved from http://www .nationalcancersusproject.org. 
Noble, K. (1987). Psychological health and the experience of transcendence. Counseling Psychologist, 15(4), 601-614.

Noyes, R., Jr., Fenwick, P., Holden, J. M., \& Christian, S. R. (2009). After effects of pleasurable Western adult near-death experiences. In J. M. Holden, B. Greyson, \& D. James (Eds.), The handbook of near-death experiences: Thirty years of investigation (pp. 41-62). Santa Barbara, CA: Praeger/ABC-CLIO.

Osis, K., \& Haraldsson, E. (1986). At the hour of death. Mamaronek, NY: Hastings House.

Pearson, P. (2014). Opening heaven's door: Investigating stories of life, death, and what comes after. New York, NY: Atria Books.

Peterman, A. H., Fitchett, G., Brady, M. J., Hernandez, L, \& Cella, D. (2002). Measuring spiritual well-being in people with cancer: The Functional Assessment of Chronic Illness Therapy-Spiritual Well-Being Scale (FACIT-Sp). Annals of Behavioral Medicine, 24(1), 49-58.

Peterman, A. H., Reeve, C. L., Winford, E. C., Cotton, S., Salsman, J. M., McQuellon, R. . . . Campbell, C. (2014). Measuring meaning and peace with the FACIT-Spiritual Well-Being Scale: Distinction without a difference? Psychological Assessment, 26(1), 127-137.

Proudfoot, W. (1985). Religious experience. Berkeley, CA: University of California Press.

Rees, D. (1971). The hallucinations of widowhood. British Medical Journal. 2, $37-41$.

Rees, D. (2001). Death and bereavement: The psychological, religious and cultural interfaces (2nd ed.). London, England: Whurr.

Rousseau, G. S. (1990). The languages of psyche: Mind and body in enlightenment thought. Berkeley, CA: University of California Press.

Sadock, B. J., \& Sadock, V. A. (Eds). (2000). The comprehensive textbook of psychiatry (7th ed.). Philadelphia, PA: Lippincott Williams \& Williams.

Shermer, M, (March, 2003). Demon-haunted brain. Scientific American, 25, 32.

Shushan, G. (2009). Conceptions of the afterlife in early civilizations: Universalism, constructivism, and near-death experience. New York, NY and London, England: Continuum International.

Streit-Horn, J. (2011). A systematic review of research on after-death communication (ADC) (Doctoral dissertation). Retrieved from http://digital.library.unt .edu/ark:/67531/metadc84284/.

Taylor, A. (n.d.). Inner healing. Retrieved from http://www.inplainsite.org/html/ inner_healing.html.

Vaisrub, S. (1977). Afterthoughts on the afterlife (Editorial.) Archives of Internal Medicine, 137, 150.

van Lommel, P. (n.d.). A reply to Shermer: Medical evidence of NDEs. Retrieved from http://www.nderf.org/NDERF/Research/vonlommel_skeptic_response.htm.

van Lommel, P., Wees, V., Meyers, V., \& Elfferich, I. (2001). Near-death experience in survivors of cardiac arrest: A prospective study in the Netherlands. Lancet, 358(9298), 2039-2045.

Weber, M. (2004). Science as a vocation. Indianapolis, IN: Hackett. (Original work published 1917)

Zinnbauer, B. J., \& Pargament, K. I. (2005). Religiousness and spirituality. In R. F. Paloutzian \& C. L. Park (Eds.), Handbook of the psychology of religion and spirituality (pp. 21-42). New York, NY: Guilford Press. 